\title{
The Relationships between Fungicidal Action on Diaporthe citri and Effect on Mitochondrial Respiration of 8-Quinolinol and Its Related Compounds
}

\author{
Kohtaro Tomono and Noriyuki Kumazawa* \\ Development and Research Department, Tomono Nohyaku Co., Ltd., \\ Kasuga, Shizuoka 420, Japan \\ *Department of Physiology, Wakayama Medical College, 9-Bancho, Wakayama 640, Japan
}

(Received November 24, 1983)

\section{INTRODUCTION}

Melanose, a rain-borne disease of citrus caused by Diaporthe citri (Faw.) Wolf, ${ }^{1)}$ is prevalent in Japan which has an abundant rainfall during the growing season of citrus. The fungus also causes stem-end rot in stored fruit and pycnidia are formed on the dead twigs of citrus trees. ${ }^{2)}$ The pycnospores are carried on leaves or fruit by raindrops, germinate, form appressoria and penetrate the tissues. After penetration, the fungus dies and the fruit does not become corrupt, ${ }^{3)}$ but reddish brown to dark brown spots caused on the surface of leaves or fruit form tear-streaked or mud-caked pattern in case of heavy infection and lower the grade of fruit because of the appearance. Therefore, melanose is one of the most important diseases of citrus in Japan. Copper 8-quinolinolate, a chelate compound of 1 molecule of copper ion and 2 molecules of 8-quinolinol, has strong inhibitory effect against $D$. citri. It does not cause rash on the skin as zineb or mancozeb does and the toxicity to mammals is low. ${ }^{4-6)}$ Moreover, it does not cause phytotoxicity as inorganic copper compounds do.

In the previous paper, ${ }^{7)}$ a possibility was suggested that the inhibitory effect of 8quinolinol on the growth of Alternaria kikuchiana is related to the uncoupling effect and 8-quinolinol acts as a carrier of copper ion to afford the synergistic fungicidal action of copper ion and 8-quinolinol, because mitochondrial membrane or some related biomembrane is permeable to uncouplers. In this paper, we studied the relationship between the inhibitory effects of some compounds related to 8-quinolinol on the growth of $D$. citri and their effects on respiration of rat liver mitochondria, in order to clarify the mode of action of 8-quinolinol on D. citri.

\section{MATERIALS AND METHODS}

Spore-hornes of pycnidia produced on an autoclaved citrus twig culture of $D$. citri were collected and suspended in sterile distilled water containing $2 \times 10^{-2} \mathrm{M}$ fructose to give an appropriate density (100-120 pycnospores in a field of $150 \times$ microscope magnification). This was then mixed with the same volume of solutions of quinoline, 2-,4-,5-,6-,7- and 8quinolinols (3-quinolinol was unavailable), $\alpha$ naphthol and 5,7-dihalogenated-8-quinolinols. EDTA (final concentration; $10^{-6} \mathrm{M}$ ) was added to solutions of 8-quinolinol or 5,7-dihalogenated-8-quinolinols in order to eliminate trace metals contained in the solutions. ${ }^{8-10)}$ Drops of the suspensions ( $\mathrm{pH} 6$, adjusted by $13 \mathrm{~mm}$ phosphate buffer) were placed on alcoholtreated epidermal strips of onion bulb and incubated at $25^{\circ} \mathrm{C} .{ }^{11}$ ) After $24 \mathrm{hr}$ incubation, pycnospore germination rate and hyphal penetration rate were observed under a microscope.

Effects of compounds relative to 8-quino- 
linol on respiration of rat liver mitochondria were observed with a Clark type platinum oxygen electrode. The suspension medium contained $0.2 \mathrm{~m}$ sucrose, $2 \mathrm{~mm} \mathrm{MgCl}_{2}, 1 \mathrm{~mm}$ EDTA $2 \mathrm{Na}, 10 \mathrm{~mm}$ succinate $\cdot 2 \mathrm{Na}$ and 10 $\mathrm{mm}$ K-phosphate buffer ( $\mathrm{pH} 7.4)$. The medium also contained $1 \mu \mathrm{g}$ of rotenone per $\mathrm{mg}$ of protein, in order to inhibit the electron transport system except for the succinate system.

\section{RESULTS}

$I_{50}$ of compounds relative to 8-quinolinol on pycnospore germination of $D$. citri is shown in Table 1. Inhibitory effect of these compounds was in the order of, quinoline $\fallingdotseq$ quinolinol $<\alpha$ -

Table $1 \mathrm{I}_{50}$ of 8-quinolinol and its related compounds on germination of Diaporthe citri.

\begin{tabular}{lc}
\hline \multicolumn{1}{c}{ Compound } & $\mathrm{I}_{50}(\mathrm{M})$ \\
\hline Quinoline & $3 \times 10^{-3}$ \\
2-Quinolinol & $3 \times 10^{-3}$ \\
4-Quinolinol & $7 \times 10^{-3}$ \\
5-Quinolinol & $5 \times 10^{-3}$ \\
6-Quinolinol & $1 \times 10^{-3}$ \\
7-Quinolinol & $3 \times 10^{-3}$ \\
8-Quinolinol & $1 \times 10^{-3}$ \\
a-Naphthol & $3 \times 10^{-4}$ \\
5,7-Dichloro-8-quinolinol & $5 \times 10^{-5}$ \\
5-Chloro-7-bromo-8-quinolinol & $3 \times 10^{-5}$ \\
5,7-Dibromo-8-quinolinol & $5 \times 10^{-5}$
\end{tabular}

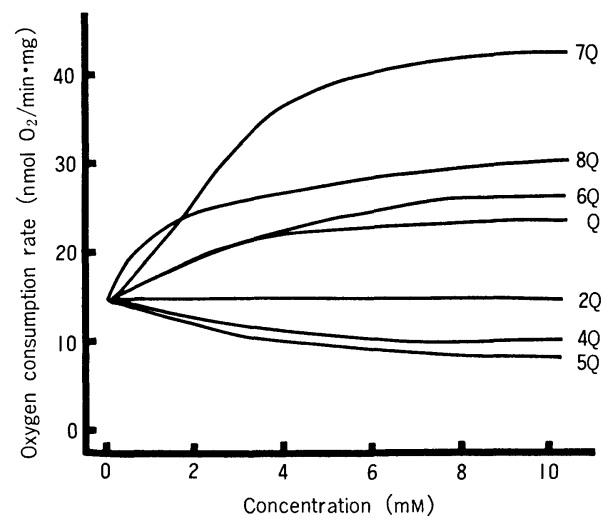

Fig. 1 Influence of quinoline and quinolinols on oxygen consumption rate of rat liver mitochondria.

Q: quinoline, 2Q: 2-quinolinol, 4Q: 4-quinolinol, 5Q: 5-quinolinol, 6Q: 6-quinolinol, 7Q: 7-quinolinol, 8Q: 8-quinolinol. naphthol<5,7-dihalogenated-8-quinolinol. $\quad \mathrm{I}_{50}$ of these compounds on hyphal penetration was about half of that on pycnospore germination.

Then, we studied the effect of these compounds on the respiration of rat liver mitochondria. In a series of experiments, 2-quinolinol had no influence on respiration even at $10^{-2} \mathrm{M}$ and 4-quinolinol and 5-quinolinol slightly inhibited at $10^{-3}$ to $10^{-2} \mathrm{M}$ (Fig. 1). Quinoline, 6-quinolinol, 7-quinolinol and 8-quinolinol accelerated respiration at $10^{-3}$ to $10^{-2} \mathrm{M}$ (Fig. 1), $\alpha$-naphthol accelerated at $10^{-4}$ to $10^{-3} \mathrm{M}$ (Fig. 2), 5-chloro-7-bromo-8-quinolinol accelerated at $10^{-5}$ to $10^{-4} \mathrm{M}$ and 5,7-dichloro8-quinolinol and 5,7-dibromo-8-quinolinol also

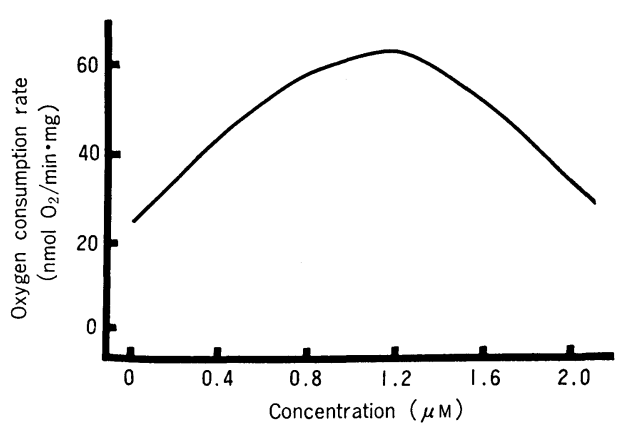

Fig. 2 Influence of $\alpha$-naphthol on oxygen consumption rate of rat liver mitochondria.

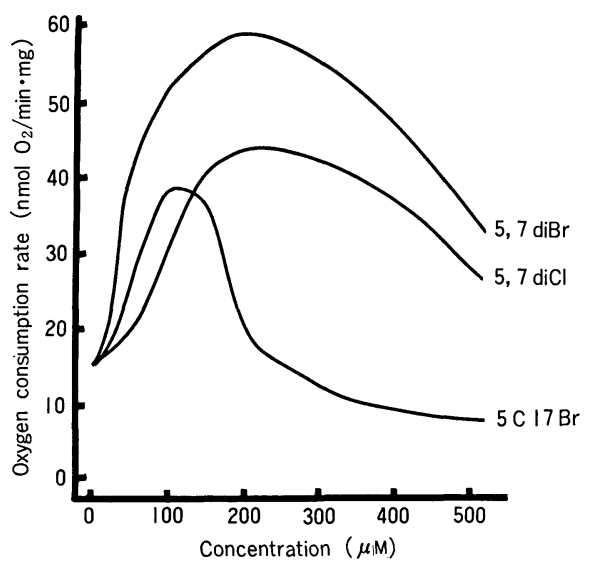

Fig. 3 Influence of 5,7-dihalogenated-8-quinolinols on oxygen consumption rate of rat liver mitochondria.

5,7diCl: 5,7-dichloro-8-quinolinol, 5C17Br: 5-chloro-7-bromo-8-quinolinol, 5,7diBr: 5,7-dibromo-8quinolinol. 


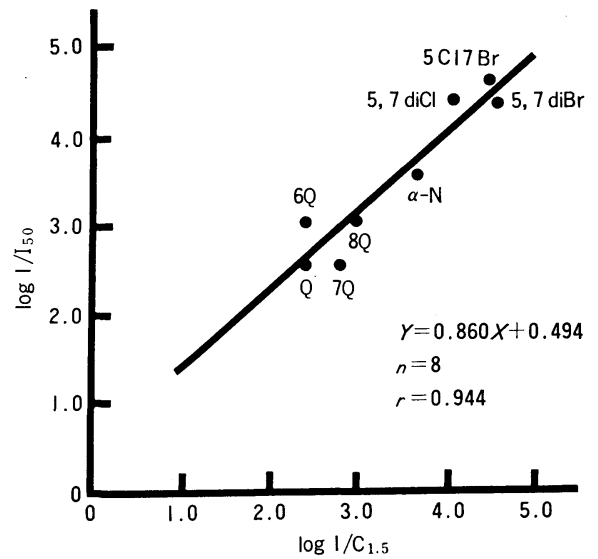

Fig. 4 Relationship between $\log 1 / I_{50}$ and $\log$ $1 / C_{1.5}$, where $C_{1.5}$ is the concentration that induces respiratory acceleration of rat liver mitochondria to 1.5 times.

$\mathrm{Q}:$ quinoline, 6Q-8Q: 6-quinolinol-8-quinolinol, $\alpha-\mathrm{N}: \alpha$-naphthol, 5,7-diCl: 5,7-dichloro-8-quinolinol, 5Cl7Br: 5-chloro-7-bromo-8-quinolinol, 5,7diBr: 5,7-dibromo-8-quinolinol.

accelerated at $10^{-5}$ to $2 \times 10^{-4} \mathrm{M}$ (Fig. 3). Relationship between inhibitory effect of compounds relative to 8-quinolinol on germination of $D$. citri and their effect on mitochondrial respiration is shown in Fig. 4. There was a close correlation between them $(n=8, r=$ 0.944). Inhibitory effect of these compounds on hyphal penetration of $D$. citri and their effect on mitochondrial respiration were also closely correlated, because $I_{50}$ of all of these compounds on hyphal penetration was about half of that on pycnospore germination.

\section{DISCUSSION}

When no EDTA was added, 8-quinolinol revealed a two-peaked dosage-response curve as was shown in the case of Stemphylium sarcinaeforme. ${ }^{12)}$ It was not found on Alternaria kikuchiana. ${ }^{7)}$ When no EDTA was added, $\mathrm{I}_{50}$ of 8-quinolinol on germination of $D$. citri at lower concentration was $6 \times 10^{-7} \sim 2 \times 10^{-6} \mathrm{M}$ and that at higher concentration was $10^{-3} \mathrm{M}$. Two-peaked dosage-response curve was also observed on the slide glass unless EDTA was added. Therefore, the inhibitory effect at lower concentration is considered to be due to chelate compound of 8-quinolinol and trace metals contained in reagents or $D$. citri itself. On the other hand, 5,7-dihalogenated-8-quinolinol did not reveal two-peaked dosage-response curve even when no EDTA was added, that is, $\mathrm{I}_{50}$ of them was not influenced by EDTA. This might depend on the fact that chelate activity with trace metals was less than that of 8-quinolinol.

Quinoline, 6-quinolinol, 7-quinolinol, 8quinolinol, $\alpha$-naphthol, 5,7-dichloro-8-quinolinol, 5-chloro-7-bromo-8-quinolinol and 5,7dibromo-8-quinolinol inhibited the growth of D. citri, i.e., hyphal penetration or pycnospore germination, at nearly the same concentrations as they accelerated mitochondrial respiration. Among the compounds tested, a close correlation was found between $\log 1 / I_{50}$ and $\log 1 /$ $C_{1.5}$, where $I_{50}$ is the concentration of $50 \%$ inhibition on germination of $D$. citri and $\mathrm{C}_{1.5}$ is the concentration which induces respiratory acceleration of rat liver mitochondria to 1.5 times. Judging from this fact, the inhibitory effect of 8-quinolinol and the related compounds against $D$. citri seemed to be related to the uncoupling effect.

\section{REFERENCES}

1) B. F. Floyd \& H. E. Stevens: Fla. Agric. Exp. Stn. Bull. 111, 1 (1912)

2) Y. Homma \& S. Yamada: Bull. Hortic. Res. Stn. Jpn., Ser. 89, 99 (1969)

3) Y. Arimoto, Y. Homma \& T. Misato: Ann. Phytopathol. Soc. Jpn. 48, 559 (1982)

4) P. G. Benignus: Ind. Eng. Chem. 40, 1426 (1948)

5) S. Yamamoto: Agric. Hortic. 42, 1235 (1967)

6) M. Koizumi: Kankitsu 30 (6), 24 (1978) (in Japanese)

7) K. Tomono, N. Kumazawa, Y. Homma \& T. Misato: J. Pesticide Sci. 8, 277 (1983)

8) A. Albert: "Zoku Sentakudokusei," translated by M. Akino and S. Isaka, GakkaishuppanCenter, Tokyo, p. 135, 1977 (in Japanese)

9) A. Albert: ibid., p. 163, 1977

10) A. Albert, M. I. Bibson \& S. D. Rubbo: $B r . J$. Exp. Pathol. 34, 119 (1953)

11) K. Tomono, Y. Arimoto, Y. Homma \& T. Misato: Ann. Phytopathol. Soc. Jpn. 45, 9 (1979)

12) C. L. Mason: Phytopathology 38, 740 (1948) 
要 約

8-Quinolinol およびその関連化合物のカンキツ 黒点病菌に対する殺菌作用とミトコンドリアの 呼吸に及ぼす作用との関係

伴野広太郎，熊沢紀之 8-quinolinol およびその関連化合物の, カンキツ黒点 病菌に及ぼす生育阻害作用と, ミトコンドリアの呼吸に 及ぼす作用との関係を検討した。 quinoline，6-quinolinol, 7-quinolinol, 8-quinolinol は, 10-3 $10^{-2} \mathrm{M}$ でラ ット肝臓のミトコンドリアの呼吸を促進した。 $\alpha$-naph- thol は $10^{-3} \sim 10^{-4} \mathrm{M}, 5$-chloro-7-bromo-8-quinolinol は10-5 $10^{-4} \mathrm{M}, 5,7$-dichloro-8-quinolinol 打よび 5,7dibromo-8-quinolinol は $10^{-5} \sim 2 \times 10^{-4} \mathrm{M}$ で呼吸を促進 した。 これらの化合物は, ミトコンドリアの呼吸を促進 する濃度とほぼ同じ濃度で, カンキッ黒点病菌の生育を 阻害した。 カンキッ黑点病菌の発芽を 50 \% 阻害する濃 度を $\mathrm{I}_{50}$, ラット肝臟のミトコンドリアの呼吸を 1.5 倍 に促進する濃度を $\mathrm{C}_{1.5}$ とすると, $\log 1 / \mathrm{I}_{50}$ と $\log 1 / \mathrm{C}_{1.5}$ との間には非常に高い相関関倸が見られた $(n=8, r=$ $0.944)$. 